\begin{tabular}{l}
\hline 寄 \\
LETTER TO THE \\
\hline
\end{tabular}

IAF 第 23 回総会*

The 23rd Congress of IAF : Vienna, Octobor 8 15, 1972

\author{
辰友信 人* $^{* *}$ \\ Makoto NAGATOMO
}

\section{IAF とは}

IAFの第 23 回総会は昨年 10 月オーストリアのウ イーンで開かれたが，私は僟会に惠まれて，この中の シンポジウムの一つにおける論文発表者として，また 総会本会議の日本代表として，これに参加することが できたので，そのふんい気を打伝えしたい，本学会は IAF を脱退しており，会員の関心むうすいかと思わ れるが，これは，ほとんどすべての宇宙関係分野を網 羅する唯一の国際的連合組織として重要なむのである ので，ことで IAF への理解を梁めていただければ声 いである。

IAF は International Astronautical Federation $の$ 略で，これはわが凿では“国際宇苖航行連盟”と訳さ れているようである，連盟の規約を読むと，その主た る目的として，宇宙航行学 (astronautics) の平和利用 の推進および知識の普及，またその広報活動，研究活 動の国際的連携，等がうたわれている.しかしてれだ けではごうも漠然として良く分からないという人多 いだろう。組織的に見ると，この連盟には宇宙関係の 学会・協会その他の団体が加入することができ，各国 から一団体が総会に打いて投票権を持つ代表メンバー (vote member) となる，わが国では現在，日本ロケッ 卜協会上日本宇宙旅行協会がこれに加入し，前者が代 表メンバーとなっている。

IAFの日常の活動は,その組織している IAA(International Academy of Astronautics) の中の各種委員 会が，個々に，情督交換，研究者の組織化などを行な っているが，その活動形態は一見グループ的という か，独立した動きに重点を括いているので，この中に 入っていないと良く分からないようである。これあ “宇宙”が一つの研究分野というよりむしろ，種々の 活動の“場”を意味していると考えればやむを得ない ことであり，IAF そのあのが大きなゆるい連合とな っているのはむしろ好ましいといえるだろう。

* 㕷和 48 年 4 月 16 日原稿受理

** 東京大学宇宙航空研究兹

\section{2. 会議の町ウィーン}

この一見，漠然とした組織がまとまりを見せるのが 年一回の “総会” (Congress of IAF あるいは写真の ポスターにあるように International Astronautical Congress) である.これは以下にも述べるように大層 にぎやかなもので，要するにお祭りさわぎだ，という 人もいる.しかし，摖りには沢山人が集まってくる 加，“学問とは真理をめぐる人間関係”という見方 からすれば，これは大変有益なあのであろう。

総会は加盟国のまわりあちで毎年開かれるが, 1972 年は前年のベルギー同様ヨーロッパ内のオーストリア のウィーンで 10月 8日〜15日の一週間開催された。

ウィーンは歴史的に有名な会議が沢山開かれてお り，町は度重なる国際会議になれ切っているはずなの に，いかにあ町をあげての歓迎といったあたたがが

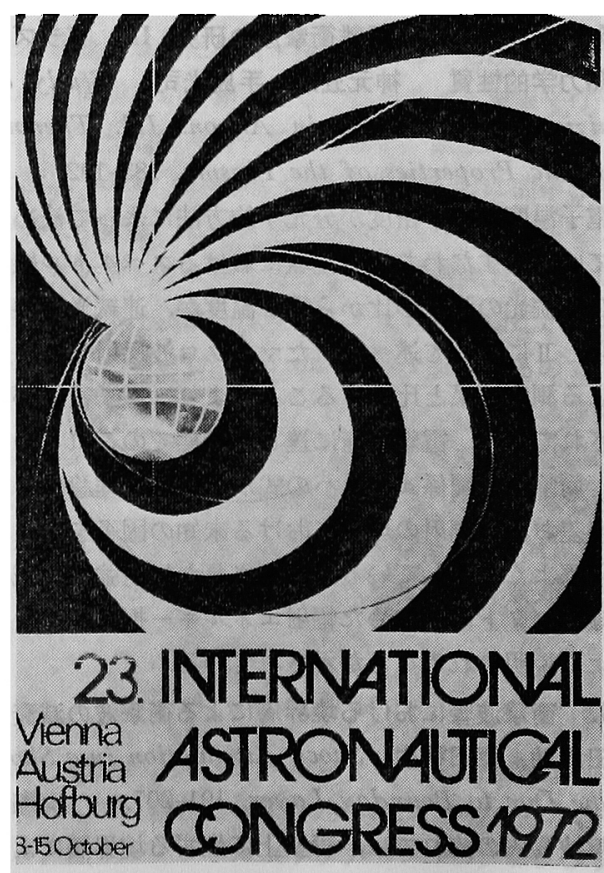

第1図第23国 IAF 総会のポスター 
ある. しかし一週間あいるとこれあやはり観光地とし ての粧いの一つであったか，と感じるようになってく る、さもありなん，オーストリアの貿易収入の第一位 は観光収入だそうである，会議は大切なお客様なの だ.

ウィーンは人も知る芸術の都．年配の方ならワルッ でダンスという楽しいふんい気を思い出されるととで

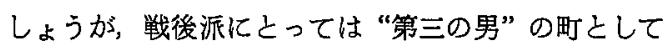
あ有名である.とじんまりとしたホテルでは日本人は 珍しいらしく，どてかで見たような顔をした番頭は私 の顔とパスポートを見比へていたが，やがてうんうん うなずいて部屋の鍵をくれた。なれない飛行機でいき なり地球の反対側に連れてとられたものだから頭がピ ンとこず, “今日は9日だからすう開会式は終わって いるな”などと考えていたら，さっきの番頭のととを 思い出した．どこかで見たような顔は“第三の男”の 映画の中で見かけたものだった。“そうか，ここはウ イーンなのだ，私はとびおきて仕度をすると，会場 のホッフブルグ宮殿に行く市内電車にとび乗った.

\section{3. 総会の内容}

複雑な IAF 総会の内容を便宣的に 3つに大別して おとう.

第 1 はセッションに分けられた発表講演で，てれら は IAF の事務局（パリ）之開催国の主催団体（今回 はオーストリア宇宙航行協会) が等口となってペーパ が一般から募集されている．このさい，採否の審査が ないも同然だそうであるが，私はとれはいいととだと 思う.

第 2 は前述の IAA 内の各種委員会の開催するシン ポジウム等で, 総会プログラム上は第 1 のセッション あのといっしょに扱われ，会場す同じ所を使うのがふ つうであるが，組織上の性格が異なっている，つまり ことで発表されたり討論されたりするペーパーは各委 員会が用意し, 多くの場合委員長を中心として予定し たあの (invited paper)である.

第 3 は IAF の総会本会議 (General Assembly) で ある. これには参加国代表メンバーが出席して，IAF の活動方針の決定，予算承認，役員の選出などを行な う.とれに関連して委員会が開かれることああるが， いずれにしてすとれらはごちらかといえば政治的で， 前二者の学術発表とは趣きを異にするすのであるま たこれらのスケジュールはプログラムには明記されて いないが期間中 2 日間位が集まりに費やされる，むち ろんしかるべき国々の代表は一䓢間いっぱいいろいる 仙しく，真面目にやろうと思えば論文発表者がこれを 兼ねるのは無理がある。
以上のようなととが分かったのは会場に行ってから である.上のような事情からすると表題で IAF 総会 といったのは“大会”という方が適切かも知れない. ただしここでは慣習に従っておこう．以下で簡単にこ の内容を紹介するが，何しろ日本加らの出席者は，私 の他に三菱電機の土屋氏だけ．NASA の籍で来てい る草雉君を入れてあ三人というありさまで, 全員でが んばってあ全会場化顔を出すととあできなかったが， アブストラクトを見ながら，また会場のふんい気を思 い出しつつ上の分類別に話題をひろってみよう.

3.1 一般セッション セッションはスペシャリス ト・セッション群とテーマ・セッション群があるが, IAF の発表講演が他の学会に比べて目立つのはテー マが広く，目新しい点であろう。“ゼロ重量状態での 材料加工”セッションでは，スカイラブとスペース・ ステーションのために行なわれた研究と思われるすの が多い. “科学宇宙船の設計”セッションではいくつ かの惑星探查プロープの計画や，米ソの実績が紹介さ れた. ESRO の金星プローブと西ドイッの HELIOS 計画汃目立つ、ロケット飛しょう体は，“宇宙輸送の 間題”というセッションに入っているが，これは“地 上から軌道へ”圵よび“軌道から軌道へ”という2つ のセッションに分かれている，とこでは当然，話題の スペース・シャトルとスペース・タグに関する発表が 多いと思っていたが，タグの方はともかく，地球から の打ち上げに使うシャトルの方は，後で述へる “打ち 上げコスト低減”シンポジウムに出し物をとられた感 じで, スカウト・ロケットの性能向上とか, 地上チェ ック・アウト装置のモジュール化といったありきたり の内容が多かった. “字宙生物学”は“生命科学”“生 命維持” “宇宙医学”の3セッションに分かれていた。 生命科学はオーソドックスな内容で門外漢にはさっば

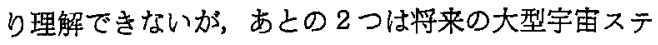
ーションに供えた大規模な宇宙農場やスペース・コロ ニーの話などプログラムは楽しそうな話でいっばいだ った. しかしあいにく一つあ聞くチャンスがなく，こ の方面の論文の多いソ連の欠席が多かったととも確認 できず残念だった. “資源衛星”や“教育用衛星”は テーマ・セッションとして3つ設けられていたが， ERTS (アメリカの資源衛星) が活やく中のととであ り，遠隔検知技術や公害対策なよ゙はやりのテーマを取 り扱っているせいああってにぎわっていた.

この範ちゅうに含めていいかよく分からないが,“学 生会議" (International Student Conference) という いかにあ IAF の趣旨にそった，興味のある催しがあ る.これはオーガナイザー，発表者とあ学生であっ て，提出された論文をシニアである各国專門家数名か 
ら成るレヴュー委員会の査読をうけることになってい る. 今回は第 2 回であるが 3 セッション相当をてれに あてていた．プログラムで見るとヨーロッパが圧倒的 に多く、さすがのアメリカも，高い足代を出せる学生 は少ないらしい，取り上げているテーマは基整的なる のが多いが，若いうちにてういうととを卒業して，国 際会議にも慣れてしまえる連中が養しい，

以上，私がIAF らしいと思ったセッションを主に 取り上げたが，もちろん “宇宙航行力学” “材料・構 造” “推進” “流体力学” 等の専門別セッションもにぎ わっている. しかし，とれらの内容は ISTS-Tokyo に比べて差がないように思える. むしろプロシーディ ングスが完全に残るという点でいえば，むしろ ISTS の方がすぐれているといえるかも知机ない，ともかく 論文題目などから察するに，てれらの尃門研究によっ て支えられ，逆にその研究を促してきた宇宙プロジェ クトが，アポロ計画で一段落した結果，研究そのもの が整理の段階を経つつあるという傾向が続いているよ うだ.

とれに対して “青少年ロケット実験の安全性”セッ ションと“宇宙活動の環境破壊に扤上ぼす効果につい て”の討論会などで取り上げている問題は “宇宙”に ついてなすべきことが，学問研究の面だけにとどまら ないととを示しているようである．乙の傾向は，実は 宇宙科学・工学そのあのの中にああらわれてきつつあ り，新しい研究は宇宙を一つの環境之考えて，ととに すへての人間活動が進出する事態に備えつつある，と いっていいと思う．次のシンポジウムやコロキウムで はてれか䫓著にあらわれている。

3.2 シンポジゥム・コロキウムシンポジゥムは いくつかの委員会が開催するので，すへてを知るわけ にはいかなかったが，私が関係のあった“宇宙救急シ ンポジゥム”についてやや詳しく内容をのへて，他を 推しはかることにしよう。このシンポジウムはすでに 第 5 回で，每回プロシーディングスを残している．委 員会は “宇宙救急代関する研究委員会”で，委員長は 発足以来アメリカはテキサスのキャンベル博士 (Paul A. CAMPBELI) であった. シンポジウムは議長の同博 士を中心にまとまったふんい気をあっており，参加者 は顔見知りの人が多いなどやかさ之，委員会の平常の 活動のしめくくりをしなりればならないという意気込 みのようなあのがある. 新顔は私一人らしかったが， キャンベル博士が筆者の上司玉木教授と知己の間柄で あること，また私のペーパーをあらかじめ同博士の旧 知であり，この委員会のメンバーである慈恵医大の佐 伯教授が売り込んで下さったので，スムーズに仲間入 りさせてもらった：むしろ “宇宙救急”という風変わ
りなテーマで同好の士を得たために，国内の学会など よりはむしろくつろいだ感じであった，シンポジウム の内容は，“宇宙救急”そのあのの説明になるので, これはまたの機会に本誌の編集委員に取り上げていた だくととを期待して，省略したい。

シンポジゥムとは別に “宇宙救急化関する研究委員 会”が開かれ，シンポジウム発表者屯招待されてふん い気を味わった．他のセッション同様，シンポジゥム ではソ連が欠席して発表が取り消されたが, 次回 IAF 総回がソ連で開催されるととああって，宇宙生物学の アダモヴィッチ博士が出席して，来年の方針を打ち合 わせた．ことで，委員長加，元来医学関係者の多い この委員会の活動を将来工学関係者も合めてより広い あのとしたいので，シンポジウムの名称を"宇宙救急 と安全性”としたいと提案され了承された．乙れにつ いては，筆者らの発表 “人工飛行物体之の衛突に対す るスペース・ステーションの安全性”の内容を考元合 わせた上での提案と察せられて，大変うれしかった。 またとの席で，長年とのむつかしい委員会をまとめて こられたキャンベル委員長が同じくアメリカのボルシ ャー副委員長と交代したい冒申出があって皆で労をね ぎらい了承した。

ての他のシンポシゥム等についてー言ずつ、“宇宙 航行コスト低减”シンポジウムは, スペース・シャト ルとタグの話が中心であるが，アメリカと西ドイツが 開催しているようなもので，平素の両国の協力ぶりを 示すように発表は二国が独占していた. “宇宙航行の 歴史”シンポジウムは，どんな人が聞くのかと思って のぞいたが，意外汇沢山の聴采がいた：これる，あう 6 回目, そろそろ日本のロケットの昔話を, 長老のど なたか行って話してきてあいいのではないかと思った しだい。ぜひ聞きたくてはたせなかったのは，一つは “国際月面実験室” (Lunar International Laboratory 略して LIL) で，プログラムによると，アメリカ，ソ 連，ブルガリア，チェコ，フランスなどの発表があっ たらしい。とのあたりでのホラの吹き合いは楽しかる うと残念がる.むう一つは “宇宙での原子力動力之推 進”で，これは当地に本部を持つ，国連の国際原子力 機関 (IAEA) との共催で, 場所も IAEA 本部に移し て開かれたため，ペーパーの一部を入手しただけであ る. 内容的には，計画がスロー・ダウンして新味のな いアメリカの現状墾告とどうであいいようなととの書 いてあるソ連の出し物は，つまらなく， ELDO の原 子力ロケットの計画と西ドイッで開発中の（残念なが らその直後に中止になった）宇宙用原子炉の発表が目 立っていた. とくに ELDO のあのはわれわれのグル ープのむのと比へて “1日の長”位しかない代物で, 


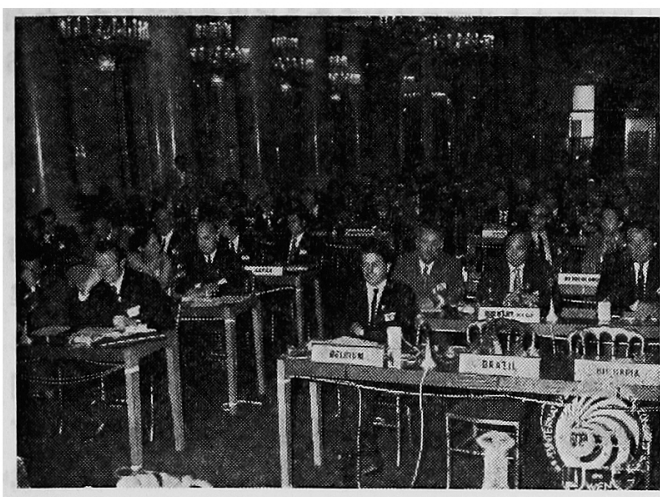

第 2 図第23 回 IAF 総会のゼネラル・アセンブリ風景

後でお互いになぐさめはげまし合った．

コロキウムは宇宙空間 (outer space) の法律に関す るもので，てれは何と 4 せション分もあって，会場 は大にぎわいだったが，後日，アヴィエイション・ウ イーク誌を見ると実際面白かったらしい，ロケットと 人工衛星が主体のわれわれから見ると，“やれやれ宇 宙もとんなになって＂它いう気持になる. そうして 悲しむ人もいるだろうが，私はどちらかといえば喜ぶ 方である. このほかには，CETI（地球外知的生物と の通信）に関する会合が IAFにおいてはじめて開か れた.

3.3 総会 (General Assembly, Plenary Session) 3日目になるまで私は何故とれが IAF の Congressな のかよく分からなかった. 何故なら，プログラムに は, 総会のことは出ていないし，その筋の動きを伝え てくれる知人はいないし，ただ，東京を発つときに“す し君より年長の日本人がいなかったら，日本の Chief Delegate たるべじという謎めいた伝言があっただ けだからである. しかし，当日，あう一人の（しかむ 私より若い）土屋氏がとんできて，国名の札が並んだ 会場が作られているが，日本の席にだれか坐らなけれ ばいけないのではないかといわれたとき，当然のよう にその席についたのである. そのうち, これがただ坐 っていれば良いというあのではないてとがだんだん 分かってくるのだが，そのときはすでにおそしであ る.

議長はジェスチャーたっぷり, 表情豊かな IAF 会 長のジャモッティ (JAUMOTTE) 教授で, あらかじめ 配布された議事次第に従って，大声で議事を進めてい くさまは，まことに見事で，英語でしゃべっていたか と思うと，フランス語になっていたり (英, 仏, 独, 露, 西， 5 力国語が公用語）ただでさえ良くわからな い内容はすっかり混乱して，しばし呆然としていた。 同時通訳のイヤホンをきくと，どうやら英語で一回い ったととをフランス語でいいなおしているらしい。内
容あ前回議事録の確認をしているらしいととがわかっ てきた.

前回議事録の中に，わが “日本航空宇宙学会”が財 政上の理由で脱会するという記録があった，そのほか に，会費湍納で除名されたイタリアの団体のととが出 ていたが，てれに比べると随分いさぎよいというか皘 極的な行動と受け取られそうである.IAFでなりを ひそめている日本としては目立った動きだか，残念で あった。

そのうち次期役員選出のための指名委員会が決めら れて日本がてれに入った.

さらに次回総回の議題にうつり，ソ連代表加ら，ア ゼルバイシャン共和国の首都バクーで 10 月第 1 週に 開催したいと提案された．ソ連開催の噂は前から聞い ていたのでモスクワだとばかり思っていたが，意外だ った. 期日については，アメリカがスカイラブの 3 回 目の飛行があるとかでずらしてくれ，といい二三のや りとりがあった後，第 2 週つまり 8 日から 15 日まで に移され決定された。

このあと，総会の催し物，刊行物などについて議題 が討論採決された後，第1日目は散会した.

やれやれと思ったとたん，今，決まったばかりの指 名委員が集まって，“今からすぐ日程を打ち合わせる 加ら”といって，連行されてしまった．どういうとと かよくわからないが，5か国 5 人の委員会じゃ逃げ出 すわりにもいかない，翌日の午前中に委員会を開いた が，委員長のイギリス (BIS)のカーターさんが徹底的 にやる気を抗しているので, 総会にばんやり坐って いるのとはわけが遧ってきた。 まず，わかったふりを していることができない，仕方がないので時々話をや めてあらって，亡なりに坐っている東ドイッのホラッ クス氏にリフレイズしてあらう，一方，スペインのマ チウサンチョ氏はこの委員会には毎回でているという 強者であるが，乙の人も時々わからなくなってしまう らしくて，となりのポーランドのヴォルチェク氏にス ペイン語で通訳してあらっている. 話の進行ととあ に，乙の東西 2 加国 2 組の組み合わせが定着してき た. だれかが自ていたら全くこっけいな光景だったる うが，乙の委員会は人事を扱う絶対秘密の集まりであ るから，部屋にはだれも入ることはできないおおか げで，内心 “へえ，そんなるのか?”之びっくりして しまうような話をいくつか聞かされあした，役員候補 の人選は，委貣長のリストを基本にして，㮌調に進ん でいったが，最後の一人であめて，ての日はこれで終 わりになってしまった. あめでとの発端は“いつも 同じ顔ぶればかりじゃないか，あっと若いのを入れた らどうだ”というもっともな意見と，それではだれに 
するがという問題であったが，翌日集まったときは委 員長が納得してまるくおさまってしまった．

第 2 日は全体の会期もあと 1 日という 13 日に開か れ，役員候補の名薄と選出基準が示された. ここで委 員会メンバー国の 5 加国は替成の挙手をしなければな らないと仕込まれていたが，乙れす上手にできて，会 長のイタリヤのナポリターノ教授，首席副会長のソ連 のセドフ博士以下の役員が決定したが，選出基準につ いては規約改正の要ありとかで次回まで持ち越され た.

かようにして短期間で徽底的に IAF 上は何ぞや之 いう教育をうけたが，ぼうあまだ良く分からないとて ろがあり，IFA の複雑さを悟っただけである.

\section{4. その他の催しの中から}

てんな調子ですっかり忙しくなってしまったが，残 りの催しの中から二三とり上げてみる.

印象に残ったのは2日目の昼に行なわれた，フォ ン・ブラウン博士の講演で，乙れはいつあガラガラの 広いホールを超満員にした. 当日, 講演はドイッ語で されるというので, 同時通訳のイヤホーンを確保して 英語を聞く，前捄きは “久しぶりにドイッ語で話をす るので下手になっているけどよろしく”ということで あった。あちろん大部分の德衆はドイッ語を話す人達 で熱心に聞き入っていた。

博士にとってはオーストリアといえば故国ドイッも 同然なのであろう，それに，NASAをやめて民間会 社俰ったせいもあるだろう，大変くつろいだ感じ で，ハンガリーとの国境地帯バーゲンランドへの長い バス旅行にあ参加して，のんびり故郷を楽しんでいる という感じがした.

会場のふんい気にあおられて日本す何かしようかと 前述の二人之相談して, 持参していった第 2 号科学衛 星 “でんば”の打ち上げのフィルムを見せてやろうと いうことになって事務局にかけ合った. 案外簡単に OK がでて, フィルム・イブニングに, 西独, 米, ソ の映画と一諸に上映するという，前口上書を作ってく れといわれて，“これは日本の科学衛星計画の一部を 示すむのである. 日本にはてのほかに NASDA とい 本㫦的な機関があって…...”というううととを書い て渡しておいた。

この催しはウイーン市民に開放されたので，子供も 沢山入って日本のロケットの胦画を見たはずである. まず，西ドイッの映画はマニピュレータのぱっとしな いもので，ソ連のはサリュート1号の長編もの，アメ リカはマリナーの映画である. どのフィルムも長く， 最後が日本で時間は 9 時でろになるというので，後を
土屋氏にまかせてワインを领みに出かけてしまった。 お荟で私は罚があたってしまうのだが，わが M-4 S の映画の評判は上々で, “むっと長い映画にしろ”之 が日本語でナレーションをやれ”という激励が沢山 あったそうである.

ワインといえぱ，ウイーン市公会堂 (Rathaus) で開 かれたレセプションは素晴しかった。 まず，荘大な建 物に入って見あげるシャンデリヤだけでも，われわれ 田含者を招ごろかすに十分であったが，参加者は昼間 の会場の 2 倍近い 1,500 人以上だったといい，イヴ ニング・ドレスの御婦人方がこんなに沢山いるのを見 たのも初めてだったささて，ウイーン市長の歓迎の辞 ではじめはおでそかにはじまった式も，赤白のワイ ンが飲み放題で大きなグラスが空になっているときが ないという結構なサービスに，だんだん乱れて，くだ をまき，抱き合うていたらくよなり，とうとう，皆， 午前様になってしまった.

\section{5. 世界の動向と日本}

以上，大ざっぱに IAF 第 23 回総会のあらましを のべたが，これを通じて，私は，もう一つの世界の存 在に気がついた. その世界は，宇宙の海へ乗り出す人 々の集まる港町のふんい気をかもし出していた. そて には，新しい船や航海用具を作る，技術者や科学者が おり，まだ見ぬ陸地に未知なものを求める探検家や博 物学者の期待があり，さらにひと山あてようとする 山師と金持がかけまわり，港の酒場は，何かいいと之 をさがしに来る人々でにぎあう，ての世界には，宇宙 はすでにわれわれのあのであるという自覚とゆとりが ある. そして，ひざをつき合せて語る所から，国境を 越えた協力関係が生まれてくるという実感があった.

ここから見た日本の宇宙の世界はユニークである. 今の所，MロケットとNロケットを作って打ち上げる ことが宇宙活動の主たるものであり，それ以上であ以 下でも相手にさ机ず，時間のスケールと外の世界を忘 れたように，事が進行しているように思え，いずれす ぐにこの世界にあどらねばならない身ながら不思議な 感じがした．乙れは別の世界を一つ形作っており，べ スト・セラー“日本人とユダヤ人”の著者，イザヤ・ ペンダサン氏のいう日本教の世界の一つの典型加知 れない.

しかし世界の方は日本に無関心ではいないＩAF総 会を“ソ連の次は日本でやったらどうかね”とどてか の代表加らいわれた. “でもとこ $3 ， 4$ 年は予定が立 っているようだから”というと, “いや. 日本がやる といえば，他の国は吹っとんじゃうよ”ということで あったし. 国連の宇宙空間利用委員会 (?)のメンバ 
一は，この日本代表をつかまえてこういった。“国連 はいよい上行動を技とすがそのターゲットは日本であ る.”と，しかしその内容は秘密であった，非力にし て，私にはこういう動きにたいして，これ以上の受け 答えはできなかったが，あう少し何かしなければいけ ないのではないか，と感じることはできた。

\section{6. あとがき}

こういうわけで，IAF 総会は私にとって大変有意
義な経験となった、いろいろなととを学んだ点では， 百の忠告や訓辞よりはるかに教育的でさえあった， この IAF 総会出席は，東大宇宙研の“でんぱ”衛星 に関する打ち合わせのためフランスの CNES を訪問 する途中出席させてあらったものであるが，このよう な機会を作って下さった，宇宙研関係者各位および日 本代表になるととを認めていただいた日本ロケット協 会の関係者に深く感謝していることを末筆ながらつけ 加えさせていただく.
(439 ページから続く)

ある時刻におりる衝撃波の減衰は，その波面の後に生 じている境界層の各区間でよの変動圧力を加え合わせ た量として表わされる。

他方長さ $20 \mathrm{~m}$, 管径 $5 \mathrm{~cm}$ の衝撃波管で室温の空気 を用いて衝撃波の減衰を椡定した、䛠算結果を実験結 果と比較すると，上の計算法はショック・マッ八数ほ ば2.5ぐらいまで一致することが確かめられた。

ただし本論文は，膜破裂後，境界層が管内いっぱい に発達するまでの間について考察したもので，この間 について適用できるあのであり，衝撃波がさらにずっ と進行して後の流れが十分発達した管流となった部分 については考えを新にしなければならない。

5. 最適化手法を用いた回転琶機の高度・速度限界 の推定 古茂田真幸 Prediction of Height-Velocity Boundaries for Rotorcraft by Application of Optimization Techniques. 208-228. 回転翼航空機の高 速線図および臨界決定点を推定するために，最適化手 法を応用した一つの解析法を提案した．回転翼航空機 の運動を記述する系の方程式ならびに各制限条件式を
導き，各限界点に対応した遷移飛行について，その間 に生ずる高速変化を最大または最小にするような最適 問題を設定する，パイロットが理想的な制御要素とし て動作するとしたときの最適制御入力，およびそれに 伴って実現される理想的な高速度限界がこれらの最適 問題の解として与えられるてと，および理想的入力か ら冕脱した誤操作の影響は最適化の過程で得られたイ ンパルス応答関数によって近似的に推定されるとと， が導かれた. 提案された解析法の合目的性をしらべる ために，高度速度線図の高ホバ点および限界速度点加 らの㹂急着陸，臨界決定点からの離陸中止ならびにそ こからの一発不作動上昇の各飛行についての数值例を 示した. 特に高ホバ点からの婜急着陸については米国 連邦航空局で行なった飛行試験結果之比較した検討を 含めてある．乙れらの結果から，問題に含まれる各パ ラメタの影響加推定され，統一的な飛行試験計画およ びデータ処理のやり方が得られることが示唆されてい る.

\section{部門委員会の活動方針と計画}

\section{空力部門委貴会}

本部門委員会の活動については，昨年度委員会から 引き継ぎ，第 4 回年会講演会“熱流体力学シンポジウ ム”(昭和 48 年 4 月) に参加して頂いた講師の方々の ど協力によって，学会誌特集号刊行の準備をすすめて いる. 新しい空気力学の分野の展望と研究成果が紹介 される予定です.

講演会などにつきましては，秋期に例年どおり第 5 回流体力学講演会を流体力学想談会と共催する予定 で，場所，日時などについて，各委員がそれぞれ檢討 しております，それらにつきましては，決定次第，会 告に載揭するつもりでおります：また，第 5 回年会講 演会（昭和 49 年）にはシンポジウムを計画する予定 です．会員各位のご要望に扣答えできるようなシンポ
ジウムにしたいと考えておりますので，で意見を頂け れ代幸い上存じます。

以上のほか，委員会の長期計画として風胴実験法に 関する資料の収集をすすめております．昨年度委員会 が国内風胴の所在調査と，その試験および実験法に関 する情報を調查する目的のアンケートを作成，風胴所 有機関の使用代表者各位に送付致しました．本年度に 入り，その回収と調查資料の整理を行ないつつありま す. 調查の対象とした風胴は，測定部断面 $1 \mathrm{~m}$ 以上 (煙風胴を含む)，超音速以上の風胴では $0.2 \mathrm{~m}$ 以上で す.とれらの結果がまとまりましたら，本部門委員会 のみでなく，広く有識者のご意見を参考として，その 活動を拡げて行きたいと思っております。

(委員長 和田 勇, 原稿受付 48.5.17) 